\title{
A Missed Opportunity or Party Rational? Ambivalent French Communists in May 1968
}

\author{
Yutaka Okuyama, Ph.D
}

\author{
CEO. Crimson Academy \\ crimsonacademy@potato.ne.jp
}

\section{Doi:10.5901/jesr.2014.v4n6p435}

\begin{abstract}
The purpose of this study is the investigation of organizational behavior of the French communists in the May Movement in 1968. Particularly at the first part of the movement, a severe rivalry between the French Communist Party (PCF) and the radical student organizations occurred. Although both of them pursued the same political goals, they could not work out for a united front. Such a behavioral choice taken by the French communists enormously influenced the course of the events. Even if the atmosphere had not been ripe enough for a revolutionary movement, the actors involved could have pulled it off through instigative appeals in order to create an acute situation. Since the electoral results had clearly indicated that the PCF possessed a concrete support mechanism, the party could have a chance to grasp a casting board, even cooperating with the students. However, the PCF did not take it. Did the communists miss the opportunity? No, they did not. The French communists acted based on their party rational, combining both new and traditional ideas on that occasion. For the party, the May Movement offered them an occasion to show the public what they stood for. That was quite enough for a social movement actor as well as a political party.
\end{abstract}

Keywords: France, French Communist Party, Social movement, May movement, Radical Students

\section{Introduction}

The purpose of this study is the investigation of organizational behavior in a social movement in which various types of groups participate. As is often the case, sharing a particular goal rarely leads people to unite or to adopt particular behavioral patterns. As a result, the goal is not likely to be achieved, which disappoints general citizens who support the movement. On the other hand, the social movement organizations are likely to keep their characteristics and programs intact.

As Sidney Tarrow suggests, an organization's process of adopting behavioral patterns is dependent on four factors: the historical heritage, the socio-economic and political settings, support and leadership structures, and the organizational tradition (Tarrow, 1975).

Each organization recruits members based on the above factors. Particularly, the historical heritage and the organization's traditions help members appeal to the potential supporters. Increasing the number of members results in expanding the organization's power base and improving its financial situation as well. Thus, all group leaders encourage their members to vigorously recruit supporters.

There are two negative factors associated with enthusiastic recruitment. One is that cooperation with others to pursue even a shared goal gets to be difficult, because the members see their affiliation only as it relates to their own interests. Second, this process of self-identification with a particular group makes the social organization an exclusive, ideologically-centered, and non-goal oriented group. The top priority for the members is to promote the peculiar programs which they support, and to monitor and suppress any signs of ideological split. Especially for the political parties, as Angelo Panebianco and others suggest, firm and continuous ideological stances as well as differences among parties are major factors for the supporters to recognize their political identification (Panebianco, 1988; Sartori, 1976; Duverger, 1954; Lipset \& Rokkan, 1990).

Although the driving forces in a social movement are the citizen groups, if political parties share the same agenda and see it as an opportunity for policy articulation, they become actively involved in it. The relationship between the citizen groups and parties is determined "not only by their relative strengths and weakness at a given moment but also an evolving political opportunity structure that can affect them both" (Lipset, 1970).

In this regard, the May movement in Paris in 1968 is an interesting opportunity to observe a conflicting and complicated relationship between a political party and social movement organizations. Particularly at the first part of the movement in which the student groups initiated and dominated, a severe rivalry between the French Communist Party 
(PCF) and the radical student organizations occurred. Although both of them pursued the same political goals, the resignation of President Charles de Gaulle and, more or less, the establishment of socialism in France, they could not work out for a united front. Even massive public chaos, which would seem to help them, did not let the communists and the radical students establish a cooperative stance enough to move on to the next step. That was because they were not necessarily goal seekers. For both groups, achievement of the shared and presented goal would have merely been a secondary matter; rather, preservation of organizational purity, not influenced by the on-going developments, but by the organizational heritage and tradition, was the priority to which the members stuck.

\section{French Communist Heritage and Tradition}

The foundation of the PCF was a product of a socialist split caused by the success of the Russian Revolution in 1917. At the Eighteenth Congress of the Section française de l'international ouvrière (SFIO) in 1920, two thirds of the delegates 3,208 among 4,290 - supported a new party based on Twenty-one Conditions by the Third International (Gaucher, 1974).

The PCF went through the extensive government oppressions and the internal strife in the pre-war period (Adereth, 1984; Murphy, 1989; Braunthal, 1963; Daniel, 1968). On the other hand, the party gradually strengthened the party foundation enough to influence the national politics. Starting with the Popular Front Deal with the SFIO in 1934, the PCF cooperated with other Leftists.

A significant development for the PCF was the election of October 1945 that made the party, with a symbol of national unity based on resistance movement under the Nazis, the most powerful party in France with 26 percent of vote cast. Consequently, the communists participated in a tripartite coalition with the SFIO and the Mouvement républicain populaire (MRP) and obtained five ministerial posts including a vice-premiership given to Maurice Thorez, Secretary General of the PCF. The PCF was included in the central organ for national policy making for the first time. Thorez (1946) commented, "It is clear that the Communist Party, in its action as part of the Government and within the framework of the parliamentary system it has helped to re-establish, will hold strictly to the democratic program which has won for it the confidence of the masses of the people." Charles de Gaulle was elected President. The PCF demanded the ministerial posts of Interior, Foreign Affairs, and Defense Departments. However, de Gaulle refused. Except for the vice premiership, the posts that de Gaulle offered the PCF were relatively minor (Brunet, 1982).

Nevertheless, participation in government neither mutated nor abandoned the PCF's ultimate purpose of existence, creation of socialism in France. The next step, guided by the Soviet Communist Party, was to achieve its final and declared goal for socialism in France. At the first Constitutional Assembly session in 1945, the communist deputies proposed, rather than a bicameral assembly common to a parliamentary democracy, the establishment of a unicameral assembly based on proportional representation on a national scale. The proposal was the prototype of people's democracy-styled governments that were formed in Eastern and Central Europe one after another under strong Soviet initiative in the late 1940s.

Nevertheless, the communists' coalition did not last long. Opposing the colonial policy of the Ramadier administration and supporting an extensive labor movement, the PCF ministers resigned in May 1947. Then, Thorez shifted his attention to internal party unity. As a Stalinist, he eliminated not only those opposed the party decisions, but also those who were highly popular among supporters. At the Twelfth Party Congress in 1950, several prominent members were expelled from the Central Committee and the Political Bureau. In 1952, the two popular leaders, Andre Marty and Charles Tillon, were removed from the Secretariat and the Political Bureau. Khrushchev's anti-Stalinist speech at the Twentieth Party Congress of the Soviet Communist Party in 1956 did not influence Thorez to modify his leadership style (Tiersky, 1974, p.181). The purge continued until the Secretary General finally resigned at the Seventeenth Party Congress in 1965 (Fejto, 1967).

At the same congress, the PCF passed significant resolutions that let the party transform into a moderate body. First, the party rejected violent revolution and stressed the peaceful transition to socialism with a multiple-party system. Second, communist dedication to the dictatorship of the proletariat was dropped from the party platform. Third, internal democratic management was confirmed (Tiersky, p. 304). The purpose was to make the party available to cooperate with the other Leftists. At this point, the communists finally abandoned their ambition to dominate the French political scene by the one party rule.

This party transformation worked positively for the PCF. In 1966, the Fédération de la gauche démocrate et socialiste (FGDS), the Leftist alliance including the SFIO, agreed with the communists for an electoral cooperation. In February 1968, three months prior to the May Movement, the two groups made a joint statement that indicated the first 
step for a common program.

At this point, the PCF adopted two different stances. One of which was its radical platform based on communist inheritance and tradition. The PCF was a group of communists and supporters obedient to Communist internationalism, strongly designed and led by the Soviet Communist Party. The creation of socialism in France under the guideline of Marxism-Leninism had never been abandoned. The other was its new and moderate approach to coalition with the others based on the concept of de-Stalinization. For the communists, the way to achieve the goal was to become flexible. All in all, one thing clear was that the PCF was no longer a party of isolation, and was ready to reappear as a powerful Leftist party in French politics on the eve of the massive movement.

\section{French Student Organizations}

In France, prior to 1968, anti-Vietnam movements again animated students' activism that had stagnated since the Algerian crisis in the late 1950s. Student groups extensively organized anti-war demonstrations and rallies. At the same time, students accumulated frustration with educational environments and regulations. A number of them who already participated in political protests did not hesitate to voice their grievances.

By the time of the May Movement, a variety of student groups existed. Although all student groups of the Left presented their claims and heavily got involved in the Movement, their activities and degree of participation were not alike.

The largest student union in France, the Union national des étudiants de France (UNEF), established in 1907, had passed through constant crisis. During the Algerian uprising, the UNEF was divided into two factions. The Rightists supported the cause of the French Algerians and opposed Algerian independence, while the Leftists favored it. Then the Rightists seceded and establish the Fédération nationale des étudiants de France (FNEF) in 1961. However, the split did not end internal division in the UNEF. Power struggles among the members were commonly taken place. In April 1968, just prior to the May Movement, a group of students seceded from the UNEF and funded the Mouvement d'action universitaire (MAU) (Monchablon, 1983).

In relation to the PCF, the UNEF had no intention of establishing cooperative ground. Although a number of communist students belonged to the organization, the break with the PCF occurred in 1967. Jacques Sauvagot, vicepresident of the UNEF, pointed out three reasons. First of all, the UNEF did not trust political functioning of parliamentary democracy within which the PCF had worked (Bourges, 1968, p.18). Second, the revolutionary tendency of the UNEF did not correspond with the Stalinist body of the PCF (Lanzmann, 1968). Third, the PCF had no capacity to see the educational issues correctly (Bourges, p. 23).

The radical students at the University of Nanterre organized the Mouvement 22 mars (M22M) in March 1968 (M22M, 1968, p. 11-41). The group led the student-oriented movement in May and acted as the driving force in student activities. One leader commented that the M22M aimed at radically inspired socio-political change that replaced all existing bourgeois structures by the concept of self-management (Bourges, p. 66). The prominent leader of the M22M, Daniel Cohn-Bendid, mentioned that the dynamism of his group and the appearance of radical claims certainly stimulated the ordinary students to express their frustration toward education and aroused an interest for radical social change (Cohn-Bebdit, 1975). He regarded himself as profoundly anti-capitalist, anti-authority, and anti-communist (Bourges, $p$. 79).

The PCF organized its own student affiliation, the Union des étudiants communists (UEC), in 1956. The party was concerned about the decline of student party membership. For example, at the École normale supérieure, a prestigious college for the intellectual elites in France, 25 percent of the students had been party members in 1946; however, only 5 percent of all the students belonged to the Party in 1956 (Johnson, 1972, p. 33). Although the party tried to dominate internal management of the affiliation, the PCF failed to create coherence, because the ideological backgrounds of the members varied (Brown, 1974). Laurent Casanova, chair of PCF's World Peace Council and recipient of the 1960 Lenin Peace Prize, influenced the ideological and practical guidance until his expulsion from the PCF in 1961. The Casanova purge indicated that student and intellectual groups that opposed to the PCF policy surely existed within the UEC (Johnson, p. 48). At the same time, the Trotskyite-inclined students, who opposed the PCF policy over the Algerian issue, withdrew from the union and formed the Comité de liaison des étudiants révolutionnaires (CLER) that transformed to Fédération des révolutionnaires (FER) on the eve of the May Movement. Two radical Trotskyite and Maoist factions founded Jenuesse communiste révolutionnaire (JCR) and Union des Jeunesse communists marxistes-leninistes (UJCML) respectively in 1965. As Richard Johnson discusses, one characteristic shared by the three communist student unions was their heavy commitment to action-oriented conducts (Johnson, p. 66). One the other hand, ideological 
differences caused a sense of rivalry and made it impossible for them to organize united actions.

Overall, the French student unions shared similar traits. First of all, except for the UEC, anti-PCF norms dominated all the groups. In spite of sharing the same goal, they did not regard orthodox communists represented by the PCF officials as spiritual authorities. Sauvageot stated that the Stalinist body of the PCF did not correspond with the revolutionary tendency of his organization. Cohen-Bendit accused traditional communists, because they had begun to throw the entire concepts of communism out of party platforms (Armand \& Gervreau, 1988). Second, radical activism marked their behavioral principle. Action-oriented struggle was only a means to reach their objectives. Third, strong spiritual leaders propelled organizational activities. Their grandiose rhetoric effectively conveyed the message for the non-political student body to follow suits. Finally, except for the UNEF, the student unions kept their sizes as small as possible in order to take a role as vanguard groups. It is clear to note that the French student groups embodied the essence of the Bolsheviks and, with regarding the French communists as their equivalent to the Mensheviks, were ready to move on to the next stage acting as the Bolsheviks on the eve of the Russian Revolution (Salini, 1968; Glucksmann, 1968).

Prior to the May Movement, confrontation between the communists and anti-communist Leftist students evidently existed. On the other hand, they needed each other, if both groups prioritized their own declared goal to pursue. The student groups should have looked for political support as the PCF could provide, and the PCF wanted the strong electoral backing as the students could confer them. Student grievances could have been absorbed into the PCF platform and through the enlargement of political power given by the young voters, the communists could have taken care of the educational system in the political arena (Lesign, 1968). Thus, the mutual cooperation scheme must have given both communists and students a win-win situation. However, evidences suggest that a reality be far from that simple game.

\section{Revisiting the May Movement}

On the eve of the Movement, a political deal with the FGDS had preoccupied the communist leaders (Rochet, 1968a, February 24; "Le rapport," 1968, February 26; Lavabre \& Platone, 2003). At such a busy and critical moment for the PCF, several developments on university campuses began to be reported. They included the student protests against dormitory regulations in Lille, Nantes, Nice, Nanterre, and Strasbourg (Silvestre, 1968), a large-scale campus protest in Nanterre on March 22 and the start of a three-day strike organized by the UNEF with UEC support on March 27. A main reason for the student agitation was campus atmosphere. Those students complained about various strict regulations on campus life, crowded lecture halls, archaic and inadequate facilities, and unattractive pedagogic methods. They advocated for reforms to be undertaken in a timely fashion. What about the PCF viewpoint on the issues? The Eleventh National Congress of the UEC in April touted the communist stance. The UEC leaders emphasized three factors which resulted in deterioration of education environment. First, universities were open for bourgeois families but limited for working class and local residents. Second, the Gaullist government did not have any intention for university reforms. Third, even a university diploma lost value as a promise of employment (UEC, 1968).

Because of preoccupation with political alliance, the communists did not take the student-centered issues into serious consideration. A routine Secretariat meeting was held on March 28; however, the campus situation was not on the agenda (PCF, 1968a). Waldeck Rochet, Secretary General of the PCF, neither brought up the issue in his article in the party newspaper on April 8 nor in a Central Committee meeting on April 18 and 19 (Rochet, 1968b; PCF, 1968b, pp. 3).

Nevertheless, the students had already moved on to the next stage in Paris. On April 22, 5,000 demonstrators, including not only university students but also high school students as well as young workers, gathered in the Latin Quarter, even though their agenda was not university issues but Vietnam. On May 3, a student-initiated revolt led by the UNEF and M22M began after the announcement to close the Nanterre campus and the Sorbonne. Although the atmosphere was relatively calm at the beginning, except for some sporadic skirmish conducted especially by JCR and FER members, the police forces responded brutally against the students. One of the student stressed (M22M, p. 22), "The Police Force appeared as the symbol of total repression." On the following day, the UEC Assembly in Paris issued a leaflet claiming that a grave situation had resulted from an intense confrontation between the militants and the police forces. Fifty thousand copies were distributed on May 4 and 5 (PCF, 1968c, pp. 11).

The PCF supported the UEC theme, but blamed not only the police forces but also "Left adventurist students" and regarded them as the core of trouble. An article in L"Humanité on May 6 put it, "violent behavior of militants and the police result in isolating students from workers and from the population." Rochet suggested that the social disturbance 
were caused by extreme behavior of the Leftists who exploited the misery and dissatisfaction of the students. Moreover, the communist leader assumed that the radicals were the opponents of the principles of Marxism-Leninism (PCF, 1968d, pp.4 22). From the beginning of the university revolt, the communists made one point clear: committing violent action with the radical student groups was not on the party agenda (Moullec, 1998).

On May 6, the UNEF branch in Paris and the SNE.Sup, a leading teacher's union, organized a demonstration of 6,000 participants. It turned into severe fighting with the police forces. Eight-one demonstrators were arrested and nearly 280 were injured. The UEC decided neither to support nor to participate in the demonstration (PCF, 1968e, pp. 12).

On May 7, one day after the violent demonstration, the Political Bureau of the PCF officially issued a statement of concern about public disorder for the first time. In the statement, the communists demanded the immediate halt of police violence, reopening of universities, and liberation of imprisoned students. They also pledged to work on construction of new local and technological universities and an increase of faculty members in order to improve pedagogic methods demanded by the students (PCF, 1968f, pp. 4). At the same time, Jean-Michel Catala, Secretary General of the UEC, mentioned that class politics as well as neglect of student needs from the Gaullist regime prevented the universities transformation into modern and democratic institutions (Catala. 1968).

The PCF expressed their ambition to utilize the situation for the ultimate party goal - the establishment of socialism. As the radical students claimed, Rochet argued that bourgeois domination of society caused student frustration and triggered the revolt. Capitalism did not respond to the needs for an innovative society and the interests of citizens (PCF, 1968g, pp. 6). His argument was almost identical to radical student leaders'. In the conclusion of the May 7 statement, the communists declared ("Déclaration", 1968a, May 8) "the PCF fights for the disappearance of capitalism and the realization of socialism in France. The party struggles, consequently, for a new democracy which will assure profound transformation, especially that of the university and education."

A Secretariat meeting on May 7 indicated that the above statement was only communist-oriented rhetoric. The discussion about the student revolt was not the first thing to put on the table but came after an agenda item about Vietnam (PCF, 1968h, pp. 1-2). This placement suggested that the party leaders did not prioritize the campus revolt as a case of strong concern at the highest level meeting.

Nevertheless, the crucial matter for the PCF, unless they were to be bystanders, was how to deal with the student groups and which direction to take, with or without the protagonists in the on-going movement. Rochet occasionally repeated, the PCF neither had any intention to cooperate with the militant students nor take revolutionary action with them to attack the government. He commented (Rochet, 1968c), "the PCF has supported and will continue to adhere to the idea to replace Gaullist power of monopoly not by subversion but by a democratic way in which the popular will is clearly and democratically expressed."

In spite of communists' ambivalence toward the movement and dislike of the militant students, one thing certain for the party was that as long as they shared the same goals, the communists could neither entirely ignore the students' claims nor their actions. Moreover, the spread of student revolts on local university campuses had been reported from Bordeaux, Lille, Lyon, and Rennes by May 8. The communists could no longer keep their distance from the student body, and act as bystanders.

On May 8, the UNEF, the SNE.Sup, and the UEC with the PCF approval held an inter-group meeting where they discussed strategies and roles of each group at the planned demonstration. After the meeting, a joint demonstration with 10,000 participants began. Because of severe police response, the UNEF and the UEC leaders at the scene ordered demonstrators to disperse and to halt the march. Militant groups within the UNEF were dissatisfied with the order. On May 9, at the inter-group meeting, Cohn-Bendit and other militants called the PCF the enemy of workers (PCF, 1968i, pp. 13). On the other hand, Rochet argued (PCF, 1968j, pp. 5) that communist-affiliated students, teachers, and workers energetically engaged in the demonstration with the mass of students. Therefore, militants' claims only reflected "a distorted fact and slander against the PCF."

A large-scale demonstration of 20,000 to 30,000 participants occurred on the evening of May 10. A number of communist leaders such as Guy Ducoloné, Dominique Frelaut, Serge Boucheny, and others took part in side by side with UEC members in the first row of the demonstration. After a calm march in the Latin Quarter, the demonstrators, following a suggestion from Alain Krivine, a powerful militant of the JCR, constructed barricades to prevent police maneuvers around major streets in Paris. Before the inevitable collision with the police forces, the UEC members pulled out (PCF, 1968k, pp. 14). Clearly, the communists did not have any interest to get involved in violence with the police forces.

On May 11, the Political Bureau of the PCF issued ("Déclaration," 1968b, May 11) a statement titled "STOP THE OPPRESSION." The statement reiterated the PCF thesis that the Gaullist regime had sole responsibility for the public chaos. In addition, the involvement of the workers was already confirmed at that point; thus, the PCF strongly 
encouraged workers, students, and teachers for united action.

The heavy battle between the militants and the police forces at Gay-Lussac Street on May 12, which occurred after the inter-union session including major student groups and labor unions, no longer bothered the communists. As the PCF felt that momentum had already been shifted from students to workers at that point, it was the end of the first chapter. The May Movement continued, but the student groups exited from the central stage. The workers with economic concessions replaced the students and became the propelling force against the Gaullist government in the following stage.

What was the PCF perception of the student-dominated part of the May Movement? Did party slogan, rhetoric, and behavior during the event truly reflect substantial characteristics of the then French communists? As for the postmovement analysis, a general overview from the party was that student unity was fragile, because it was not based on legitimate principles, but on their emotional frustration. Thus, a lack of clear motivation by the student groups diverted the direction of the Movement (PCF, 1968l. pp. 5). The students were at best bewildered: therefore, the student movement without concrete perspective was not considered a road to socialism. Roger Garaudy, one of the PCF prominent leaders, presented his analysis at a Central Committee meeting in July 1968. He emphasized three levels of crisis that caused the large scale movement. At first, Garaudy pointed out a political crisis. The Gaullist regime neglected socio-economic reforms, which led to a massive social protest in May. Second, he referred to a social crisis. As a result of increasing economic discrepancy, people developed a sense of frustration and isolation. Third, Garaudy emphasized a historical crisis. Modernization was a historical phenomenon; however, the public was not ready to respond to socio-economic changes (PCF, 1968m, pp. 6). His analysis totally corresponded with a communist principle of inevitability of change. The May Movement broke out based on political, social, and historical crisis.

On the other hand, Garaudy reminded the party members at the meeting that precise understanding of and accurate depiction of the student protest were far from complete, because the student groups' motivation stemmed from a contradictory mixture of positive political consciousness and merely agitated vandalism. According to Roland Leroy, a PCF leader at the time of the Movement, the PCF failed to grasp the meanings of student revolt and their profound misery (Leroy, 1988). Claude Cabanes, vice-president of the UEC, also commented (Cabanes, 1988, May 7) "the Communist Party did not arrange in fact theoretical, strategic, and political instruments, permitting them [the students] to take full measure of the event."

Jean Pierre Le Golf similarly argued (that students were not only preoccupied with educational environment but also with Leftists' new issues focused on quality of life, which the communists had overlooked (Le Goff, 1988, May 2127). As a result, the popularity of the PCF and the UEC in the student sector did not grow, and the party had a slim chance for attracting the general student population.

What could be observed through the above discussions by the communist leaders after the Movement was that even though an analysis of the event itself, no revolutionary atmosphere was discerned, could be correct, the party failed to pay attention to the essence of the student movement. However, acting under a situation where uncertainty dominated and no concrete direction was seen, the first task for the communists was to make internal organ and function intact as much as possible. It was the way to survive even defensively, which is the top priority for every group.

For a party like the PCF, embodying two contradictory tendencies represented by ruthless revolutionary Leftists and responsible parliamentary law-makers, decision-making process within the internal organ was highly complicated, even having instituted communist-styled democratic centralism, defining vertical order flow. In other words, it was a battle ground between tradition and modification. Communist behavior dealing with the student groups indicated that although the party advocated confrontational demands to the government, the PCF stuck with the modified party agenda, being a responsible party under parliamentary democracy. For the communist leaders, modification came up prior to tradition for party decision-making under unclear circumstances like the student-dominated part of the May Movement.

\section{Conclusion}

The essential demands from the student groups on the May Movement were about educational reform. Waldeck Rochet argued that the French education system was unable to fulfill the needs and the interests of a broad layer of the populations (PCF, 1968n, p. 10 12). From the communist point of view, the Gaullist administration had no capacity to modernize the current system.

As this study shows, the student groups shared the same argument above. The communists, even not detecting any clear and supposed consequences from the event, showed strong hesitation to deal with the students. The PCF was already moving away from the revolutionary principle and looking for a political opportunity to ally with other Leftists. The 
communists simply did not want to destroy what they had achieved by taking a violent path with the radical students, which would have devastated their credibility.

Nevertheless, the PCF policy over the education issues was quite different from the students'. The communists noted that education was the prime concern for working class and local residents who had suffered from discriminatory selection based on the concept of class society. According to the communists, there were two types of education in France: one was mass education given to the workers and locals, and the other was superior one for bourgeois families to produce elites. With the communist heritage and tradition, the students were categorized "elites" and "selected people." The communists regarded them as the enemy of people and wanted to have them reeducate with the assistance from the workers.

Curiously enough, the government circle shared the similar view as the communists observed. According to Georges Pompidou (Pompidou, 1974), the then premier under the Gaullist administration, the essence of the movement was a revolt by "privileged intellectual students' against established orders. The core of those students neither possessed any particular goal to reach nor a serious policy to implement."

Such a behavioral choice taken by the French communists, not to go hand in hand with the radical students, enormously influenced the course of the events. Even if the atmosphere had not been ripe enough for a revolutionary movement, as many have discussed, the actors involved could have pulled it off through instigative appeals, physical confrontations, and violent denunciation against the government in order to create an acute situation. Since the electoral results had clearly indicated that the PCF possessed a concrete support mechanism as well as structure and recognized as a party of change in French society, the party could have a chance to grasp a casting board, even cooperating with the students. However, the PCF did not take it. Did the communists miss the opportunity? No, they did not. The French communists acted based on their party rational, combining both new and traditional ideas on that occasion, that were, namely, party mutation to a flexible body and aversion against the established orders. The students could not achieve any demands by their intensive movement. Were the communists concerned about it? No, they were not. For the party, the May Movement offered them an occasion to show the public what they stood for. That was quite enough for a social movement actor as well as a political party.

\section{References}

Adereth, M. (1984). The French Communist Party: A Critical History. Manchester, UK: Manchester University Press.

Ardagh, J. (1969). The New French Revolution. New York: Harper \& Row Publishers.

Armand, G. D., \& Gervreau, L. (ed.) Mai 68: les movements étudiants en France et dans le monde. Nanterre: Bibliothèque de documentation internationale contemporaire. 129.

Aron, R. (1969). The Elusive Revolution: Anatomy of a Student Revolt. New York: Praeger Publishers.

Bensaid, D., \& Weber, H. (1968) Mai 68: Une Répétition Générale. Paris: François maspero.

Blackmer, D., \& Tarrow, S. (1975). Communism in Italy and France. Princeton: Princeton University Press. 575-640.

Bourges, H. (1968). The French Student Revolt. New York: Hill and Wang.

Braunthal, J. (1963). History of the International, vol. 2: 1914-1943. New York: Frederick A. Praeger.

Brown, B. (1974). Protest in Paris: Anatomy of a Revolt . Morristown, NJ: General Learning Press. 69.

Brunet, J. P. (1982). Histoire de PCF . Paris: Presses universitaires de France, 1982. 84-85.

Cabanes, C. (1988, May 7). Libération. L"Humanité. pp. 3.

Camilleri, C., \& Tapia, C. (1974). Jeunesse française et groupes sociaux après mai 1968 . Paris: Centre national de la recherche scientifique.

Capdeville, J., \& Mouriaux, R. (1988). Histoire de trente ans. Paris: Presses de la fondation nationale des sciences politiques.

Catala, J.M. (1968, May 8). La résolution en crise, L'Humanité. pp. 1.

Cohn-Bendit, D. (1975). Le grand bazaar . Paris: Pierre belfond. 46.

Daniel, B. (1968). The New Jacobins: The French Communist Party and the Popular Front. Ithaca, NY: Cornell University Press.

Dansette, A. (1971). Mai 1968 . Paris: Plon.

"Déclaration du parti communist française" (1968, May 8). L"Humanité. pp. 1

(1968, May 11). L"Humanité. pp. 1.

Duverger, M. (1954). Political Parties. London: Methuen.

Gaucher, R. (1974). Histoire secrète du parti communist française. Paris: Albin Michel. 65.

Fejto, F. (1967). The French Communist Party and the Crisis of International Communism. Cambridge, MA: The MIT Press. 112-114.

Glucksmann, A. (1968). Strategie de la revolution. Paris: Christian bourgeois.

Joffrin, L. (1998). Mai 68, une histoire de movement. Paris: Seuil.

Johnson, R. (1972). The French Communist Party versus the Students . New Haven; Yale University Press.

Lavabre, M.C., \& Platone, F. (2003). Que reste-t-il du PCF . Paris: Cevipof/Autrement. 23. 
"Le rapport de Waldeck Rochet au comité central sur l’accord parti communiste-fédération." (1968, February 26) L "Humanité. pp. 5.

Lipset, S.M., \& Rokkan, S. (1990). Cleavage Structures, Party Systems, and Voter Alignments. In Mair, P. (ed.) The Western European Party System. Oxford: Oxford University Press.

Lipset, S.M. (1970). Political Cleavage in Developed and Emerging Politics. In Allardt, E., \& Rokkan, S. (Eds.), Mass Politics. New York: The Free Press, 205.

Lanzmann, J. (1968). Mai/juin 68: ce n"est qu"un debut. Paris: Éditons et publications premiers. 218.

Le Goff, J. P. (1988, May 21-27). Oui mais qui avait compris mai 68. L"Humanité (Weekly Edition). No. 27. pp. 38.

Lesign, H. (1968). Le parti communiste française et l`education nationale. Cahiers du communisme 44 (2):30.

Roland Leroy, R. (1988, May 7). Nous étions étoffés par notre stratégie, L'Humanité. pp. 33.

Monchablon, A. (1983). Histoire de l'UNEF . Paris: Presses universitaires de France.

Moullec, G. (1998). Mai 1968, le PCF et l'union sovietique, document No.1, compte rendu de l'entretien entre V.A. Zorine et G.Plissonnier. Communism. 53/54: p. 155.

Mouvement du 22 mars. (ed.), (1968). Ce n"est qu"un debut: continuons le combat . Paris: François maspero. 11-41.

Murphy, F. (1989). Communists and Catholics in France, 1936-1939. Gainsville: FL: University of Florida Press.

Panebianco, A. (1988). Political Parties: Organization and Power. Cambridge: Cambridge University Press.

PCF. (1968a). Décisions du secretariat année 1968, No.1, I. 537,

SEC.GP.GV.6ex, 4/IV/1968-C, 2

(1968b). 18,19/avril, Discours de Waldeck Rochet. Comité central. p. 3.

(1968c). Rapport au comité national, 12-13/juillet 1968. Archives Roland Leroy. Boîte 2. Dossier 1. p. 11

(1968d). Projects divers pour un rapport au comité central. Archives Waldeck Rochet. Boîte 4, Dossier 1, (3), p. 4 22.

(1968e). Rapport au comité national, 12/13juilliet 1968, Comité central. p. 12.

(1968f). Projets divers pour un rapport au comité central, Archives Waldeck Rochet.Boîte 4. Dossier 1. (3). p. 4.

(1968g). Rapport au comité central, 30mai/1968, Archives Waldeck Rochet, Boîte 4, Dossier 3, p. 6.

(1968h). Reunion du secrétariat du 7/mai/1968. Décisions du secrétariat année 1968. SEC.GP.GV.6ex, 9/V/1968-C, No. 1, 546, p. 1-2.

(1968i). Rapport au comité national 12/13 juillet 1968. Archives Roland Leroy. Boîte 2, Dossier 1. p. 13.

(1968j). Rapport au comité central, 30mai/1968. Archives Waldeck Rochet. Boîte 4, Dossier 3. p. 5.

(1968k). Rapport au comité national, $12 / 13$ juillet 1968, Archives Roland Leroy. Boîte 2, Dossier 1, p. 41.

(1968I). Journées d`études, 7-8/décembre, 1968. Archives Roland Leroy. p. 5.

(1968m). (3) Projets divers pour un rapport au comité central. Archives Waldeck Rochet. Boîte 4, Dossier 1. p. 6.

(1968n). Intervention de Roger Garaudy. comité central, Nanterre 9, julliet/1968. Archives Waldeck Rochet. Boîte, 4, Dossier 2. p. 10-12.

Pompidou, G. (1974). Le Noeud Gordien. Paris: Plon. 26-29.

Rochet, W. (1968a, February 24). Rapport de Waldeck Rochet, Comité central 1968. p. 19

(1968b, April 8). Discourse à la jenuesse, L"Humanité. pp. 5

(1968c). Les enseignement de mai-juin 1968 . Paris: Éditions Sociales. 41.

Salini, L. (1968). Mai des proletaires. Paris: Éditions socials.

Sartori, G. (1976). Parties and Party Systems, vol.1. Cambridge: Cambridge University Press.

Seidman, M. (2004). The Imaginary Revolution. New York: Berghahn Books.

Silvestre, C. (1968, February 15). Les étudiants decident a obtenir un règulement plus liberal. L "Humanité, pp. 4.

Tiersky, R. (1974). French Communism, 1920-1972. New York: Columbia University Press.

Thorez. M. (1946, November 18). French Socialists Debate Communist Order. The Times (London), pp. 6.

Tourain, A. (1971). The May Movement: Revolt and Reform. New York: Random House.

UEC. (1968). Avant projet de resolution (a pamphlet distributed by the UEC at the Eleven Congress). 